\title{
Identification Metacognitive Failure on Mathematics Problem Solving
}

\author{
Abd. Rozak \\ Student of Mathematics Department \\ State University of Malang \\ Malang Indonesia \\ abd.rozak76@yahoo.co.id
}

\author{
Subanji \\ Mathematics Department \\ State University of Malang \\ Malang Indonesia \\ subanji.fmipa@um.ac.id
}

\author{
Toto Nusantara \\ Mathematics Department \\ State University of Malang \\ Malang Indonesia \\ toto.nusantara.fmipa@um.ac.id \\ I Made Sulandra \\ Mathematics Department \\ State University of Malang \\ Malang Indonesia \\ made.sulandra.fmipa@um.ac.id
}

\begin{abstract}
This aims of this study is to describe the identification process of students' metacognitive failure in solving the mathematical problems. A total 24 students of 3rd semester STKIP PGRI Jombang ask to fulfillment test individually, then fill the questionnaire of metacognitive activity based on the problemsolving process, the result obtained 4 students have a dissonance experienced between the questionnaire of metacognitive activity and the results of his work. The interview used to confirm whether there was a metacognitive failure or not. The results showed that students $\mathrm{W}$ had metacognitive blindness in determining what was asked in the problem, the students admitted to having done metacognitive activity and did not realize the error occurred. Student $V$ have an experienced metacognitive mirage in identifying problem information where the student did not acknowledge having metacognitive activity and feels as if a difficulty has actually occurred. While student $A$ have an experienced metacognitive vandalism in planning problem solving solution, the student admitted to having done metacognitive activity and can detect the error but still continue the work process. Other metacognitive vandalism form occurs in student $F$ in applying the planning, then student unsure the rules or formulas used to calculate, but still continues the process.
\end{abstract}

Keywords-metacognitive activity; blindness; mirage; vandalism.

\section{INTRODUCTION}

Metacognition is a familiar term in the field of psychology and education. It was introduced by Flavell in 1976. Flavell [1],[2] states that metacognition is a person's awareness of cognition and independence to achieve a particular goal. Metacognition plays an important role in developing a person's thinking skills in problem-solving, as in [3] that problem solving is a complex process involving cognitive operations such as information collection and selection, heuristic and metacognitive strategies.

The mathematical problems solving process is not enough if only has one knowledge and facts about mathematics [4], but also the ability to monitor and organize the knowledge of each possesses. This is in line with the cognition-metacognition framework in problem solving developed by Artz and ArmorThomas [5] that stated the problem solving process consists of the phases that include both cognitive and metacognitive activities (Table 1).

Based on [5], cognitive-metacognitive framework episode in problem solving were: read, understand, analyze, plan, explore, implement, verify, and watch and listen.

TABLE 1. EPISODE OF COGNITIVE-METACOGNITIVE FRAMEWORK
\begin{tabular}{|c|l|l|}
\hline No & \multicolumn{1}{|c|}{ Episode } & \multicolumn{1}{c|}{ Cognitive Level } \\
\hline 1 & Read & Cognitive \\
2 & Understand & metacognitive \\
3 & Analyze & metacognitive \\
4 & explore & Cognitive and metacognitive \\
5 & plan & metacognitive \\
6 & implement & Cognitive and metacognitive \\
7 & verify & Cognitive and metacognitive \\
8 & watch and listen & Not assigned \\
\hline
\end{tabular}

Metacognitive activity consists of monitoring and regulating, which can be applied in every problem solving stage. Monitoring consists of knowledge assessment, assessment of understanding, assessment of strategy appropriateness, assessment of progress toward goal, assessment of strategy execution, and assessment of accuracy or sense of result [6]. While, regulating consists of identifying new information, changing strategy, and correcting errors.

The monitoring and regulating process occurs when a person was aware of a difficulty or uncertainty marked by "redflag" which means a warning to pause or retreat and take a certain action immediately. Three types of redflag that occur in problem solving: (1) lack of progress; (2) error detection; and (3) anomalous result [7].

Metacognitive success and metacognitive failure with a response to redflag, a metacognitive success occurs when a person can detect redflag and take some appropriate action, or 
admit there is no redflag and continue the process. Whereas metacognitive failure occurs when it was unable to detect the presence of redflag (blindness), detects the presence of redflag but the action is taken is not appropriate (vandalism), and assume there is a redflag that is not really exist (mirage).

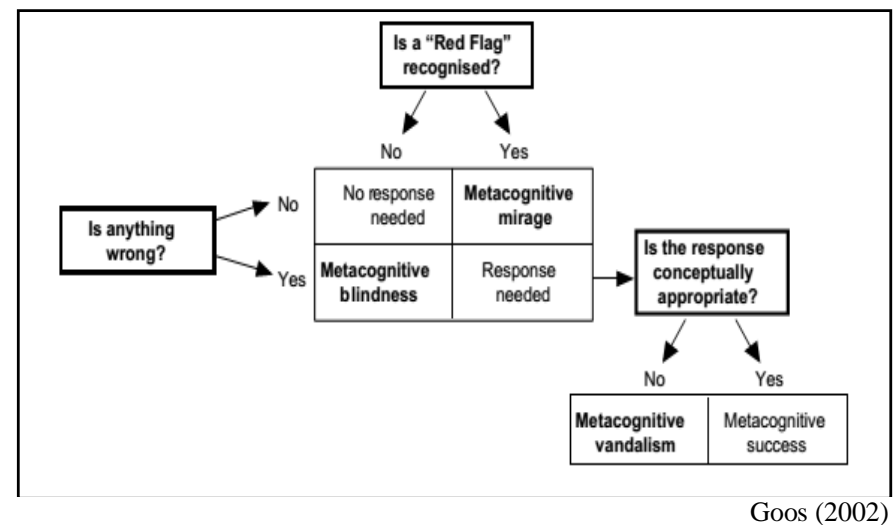

Fig. 1. Metacognitive success and failure scenarios

Based on research befor [6], identified the type of redflag and metacognitive failure at the stage of exploration, implementation, and verification. Redflag at the exploration stage is the lack of progress, is the error detection, and the verification phase is an anomalous result. At the implementation stage metacognitive blindness occurs because it does not realize the occurrence of error detection. Metacognitive vandalism occurs because there is lack of progress and takes actions that do not appropriate with the concept. While metacognitive mirage occurs because it assumes the correct answer as anomalous result so reject it.

Research on metacognit failure was conducted on group problem solving, redflag and failure were identified from group discussion transcripts [6]; [8]; [9] and focused on redflag and metacognitive failure at the exploration stage, implementation and verification [6], [9]. Researct to investigate metacognitive failure conducted when the subject work problems solving individually and conducts interviews to confirm it [10]. While in this study used different approaches in uncovering metacognitive failure, based on questionnaire of metacognitive activity adapted from Fortunato, Hecht, Tittle and Alvarez [7] and the results of the work, then confirmed by task-based interviews and developed at all the problem-solving stage according to Artz and Armor-Thomas (1992). The authors suggest that the possibility of redflag may occur at each stage [11], [12] so that metacognitive failure may occur.

\section{RESEARCH METHODS}

This research was categorized in the type of qualitative research with research strategy used was case study. Case studies are strategies in which researchers carefully investigate a program, event, activity, process, or group of individuals [12],[13]. Research instruments consist of mathematical problems, metacognitive activity questionnaires and interview guidelines. The mathematical problems was prepared by adapting the problem to Eliciting Activities Model (MEA) "On-time Arrival".

The metacognitive activity questionnaire was adapted from a self-monitoring questionnaire developed by Fortunato, Hecht, Tittle and Alvarez [7] and adapted to the stages of the cognitive and metacognitive framework [5]. Questionnaire metacognitive activity consists of 13 statements based on the stages of cognitive and metacognitive frameworks, with 3 choices: Yes, No, and unsure. Students fill out a questionnaire in accordance with experience during the process of solving the problem.

TABLE 2. STATEMENT OF METACOGNITIVE ACTIVITY QUESTIONNAIRE

\begin{tabular}{|c|c|}
\hline Episode & Statement \\
\hline \multirow[t]{2}{*}{ Understand } & 1. I made sure I understand what is being asked. \\
\hline & 2. I stated the problem by using my own words. \\
\hline \multirow[t]{3}{*}{ Analyze } & 3. I identified the information given in the problem \\
\hline & 4. I thought about the knowledge with regard to the problem \\
\hline & 5. I thought given data and goal \\
\hline Explore & 6. I used the relevant information to solve the problem \\
\hline Plan & $\begin{array}{l}\text { 7. I thought approaches that can be tried to solve the } \\
\text { problem }\end{array}$ \\
\hline \multirow[t]{3}{*}{ Implement } & $\begin{array}{l}\text { 8. I made sure that the steps and strategies I use are } \\
\text { appropriate }\end{array}$ \\
\hline & $\begin{array}{l}\text { 9. I reread the problem to make sure I'm still on the right } \\
\text { track. }\end{array}$ \\
\hline & 10. I made a mistake and had to repeat some steps \\
\hline \multirow[t]{3}{*}{ Verify } & $\begin{array}{l}\text { 11. I checked the procedures and calculations to confirm that } \\
\text { they correct }\end{array}$ \\
\hline & $\begin{array}{l}\text { 12. I looked back the method to make sure I have done what } \\
\text { the problem asked. }\end{array}$ \\
\hline & 13. I asked myself if my answer made sense. \\
\hline
\end{tabular}

Interview guidelines were prepared based on redflag indicators and metacognitive failures in the problem-solving stage referring to the cognitive-metacognitive framework.

The subjects of this research were the students of mathematics education program of STKIP PGRI Jombang in 3rd semester and have taken the descriptive statistics course in accordance with the problem. Total of 24 students ask the problem individually, after finishing the problem and then asked to fill the questionnaire metacognitive activities.

The potential for metacognitive failure occurs when there were discrepancy between the working process and the metacognitive questionnaire activity, for example acknowledging activity based on the cognitive and metacognitive framework stage indicator but not writing on the answer sheet and otherwise not acknowledging the activity or any evidence related to the indicator on the answer sheet.

\section{FINDINGS}

In this section we will describe the identification of metacognitive failure Blindness, mirage and vandalism in the problem-solving stage based on the difference between working process and metacognitive questionnaire. The results of redflag analysis and metacognitive failure of the subject then encoded with: SX.No. (ind) .R.MB 


\begin{tabular}{|c|c|}
\hline SX & Student X \\
\hline No & $\begin{array}{l}\text { Problem-solving stage based on the cognitive metacognitive } \\
\text { framework }(1-8, \text { Tabel } 1)\end{array}$ \\
\hline (Ind. & indicator of problem solving stage (1-13, Tabel 2) \\
\hline \multicolumn{2}{|c|}{$\begin{array}{c}R(\text { Redflag) }) \\
\text { result) }\end{array}$} \\
\hline & $\begin{array}{l}\text { : metacognitive failure, B (Blindness), M (Mirage), } \\
\text { V (Vandalism). }\end{array}$ \\
\hline
\end{tabular}

For example SV.2 (1). lp.B This means that student V at the understanding the problem episode occur lack of progress in determining what is asked and not aware of it, so that experiencing metacognitive blindness.

Based on student work process and questionnaire activity of metacognitive activity, from all subjects, 4 students identified metacognitive failure, then taken each one student based on potential of metacognitive failure and type of metacognitive failure happened, then conducted in-depth interview to confirm whether metacognitive failure or not.

\section{A. Metacognitive Blindness}

The problem-solving stage that refers to the cognitivemetacognitive framework begins with reading and understanding problems. One indicator of metacognitive activity in understanding the problem is to understand and ensure what is being asked. Based on the results of the work, students $\mathrm{W}$ did not write down what was asked, but in a metacognitive questionnaire activity admitted had made sure to understand what it was asking. This was the potential for metacognitive failure, where there is a discrepancy between the job and the questionnaire. To confirm it is done interview with student $\mathrm{W}$.

\begin{tabular}{|l|l|l|l|}
\hline 1. Saya memastikan bahwa saya mengerti apa yang ditanyakan. & $\checkmark$ & & \\
\hline
\end{tabular}

Fig.2. Questionnaire Questioning Student Metacognitive Activity W

$$
\begin{array}{ll}
Q & \text { : did you write down what is being asked of the problem? } \\
S W & \text { :no } \\
P & \text { : no, why you did not write? } \\
S W & \text { : because it was not in the problem } \\
Q & \text { : did you understand? } \\
S W & \text { :yes } \\
Q & \text { :If you understand what's being asked, so what's the } \\
& \text { question? } \\
\text { SW } & \text { :So I asked in that matter if I think the fastest plane brought } \\
& \quad \text { the soccer team to Soekarno-Hatta Airport because the plane } \\
& \text { at Juanda Airport often delays. }
\end{array}
$$

Based on the above interviews it was found that $\mathrm{W}$ students did not write down what was asked because they felt that there was no command to write what was asked.

Students admit to understanding what is being asked in both the metacognitive questionnaire activity and in the interview, but the results is wrong (redflag: anomalous result), so that students W experience metacognitive blindness because it makes sure to understand what is being asked but does not realize if the result is wrong (SW.2. (1) .ar.B).

\section{B. Metacognitive Mirage}

Student $\mathrm{V}$ underlines or marks several words in the problem (Fig. 6) in identifying the information of the problem, following the problem sheet, the metacognitive questionnaire activity and the part of the interview:

berangkat pada waktu mendekati pertandingan. Keberangkatan menuju Padang ditempuh dalam dua kali penerbangan berbeda karena tidak ada penerbangan langsung dari Surabaya ke Padang, penerbangan di mulai dari bandara Juanda menuju bandara Sockarno-Hatta dan selanjutnya menuiu bandara Minangkabau Padang.

penerbangan ini penting dan tidak boleh terlambat ggar tidak tertinggal pada. penerbangan berikutnya menuju Padang. Pihak manajemen memperoleh data lima maskapai tersebut dari bandara Juanda tentang keterlambatan dalam 20 hari penerbangan terakhir seperti pada tabel

Fig. 3. Problem Sheet of Student V

3. Saya mengidentifikasi informasi yang diberikan dalam masalah

Fig. 4. Questionnaire Questioning Student Metacognitive Activity V

$P \quad:$ Oh, keep looking for mean. Then in the third statement you do not write down the information or what is known from the problem. Does it already know or whether it is difficult?

SV : Yes ...., Yes I am confused

$Q \quad$ : then mark or scribble on the problem sheet for what?

SV : Which one are you?

$P$ : This. Which you underline, like not too late.

$S V$ : Yes it is

$Q$ : What is it?

SV : ....... mark.

Based on the Problem Sheet (Fig. 3) student V has actually identified the information by underlining some words, but not acknowledging them (Fig. 4).

Then confirmed through interview student $\mathrm{V}$ show difficulty and assume that underlining is not one way in obtaining information from problem (redflag: lack of progress). Thus such student V experiences metacognitive mirage (SV.3. (3) .lp.M).

\section{Metacognitive Vandalism}

Thinking about various approaches to solving problems is an indicator of the planning stage, when thinking about the approach, student A realizes that the use of the continuous delay frequency approach is not appropriate, it corresponds to the cross in its work (Fig. 5 step 5-6).

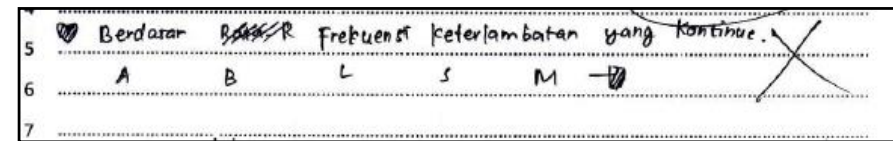

Fig. 5 Working Sheet Student A

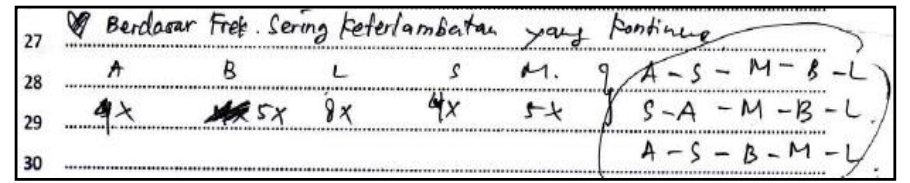

Fig. 6 Next Working Sheet Student A 


\begin{tabular}{|l|l|l|l|}
\hline $\begin{array}{l}\text { 7. Saya memikirkan berbagai pendekatan yang bisa dicoba untuk } \\
\text { memecahkan masalah }\end{array}$ & $\sqrt{ }$ & & \\
\hline
\end{tabular}

Fig. 7 Questionnaire Questioning Metacognitive Activity Student V

In the interview also found that student $\mathrm{A}$ did not use the method because theoretically did not understand it and it does not exist in theory, so the students think it wrong. Student A detects a redflag anomalous result of choosing the wrong approach, but in advanced students' work reuses that approach (Fig. 6 Steps 27-29), thus student A experiences metacognitive vandalism (SA.5. (7) .ar.V).

Another form of metacognitive vandalism occurs in student F when calculating the overall mean of airline delays within 20 days, student $\mathrm{F}$ does it without using the appropriate theoretical basis, ie the combined mean (Fig. 8 steps to 24-25).

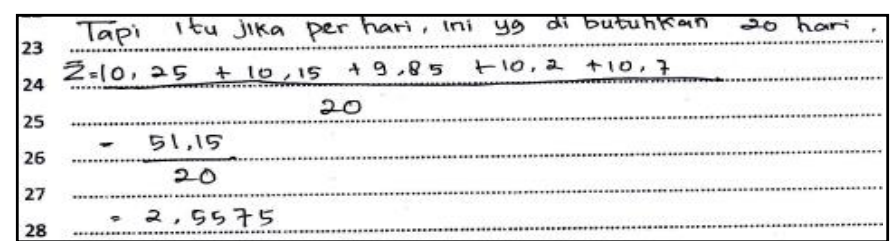

Fig. 8. Working Sheet Student F

\begin{tabular}{|l|l|l|l|}
\hline 8. $\begin{array}{l}\text { Saya memastikan bahwa langkah dan strategi yang saya } \\
\text { gunakan sesuai }\end{array}$ & & & $V$ \\
\hline
\end{tabular}

Fig. 9. Questionnaire Questioning Metacognitive Activity Student F

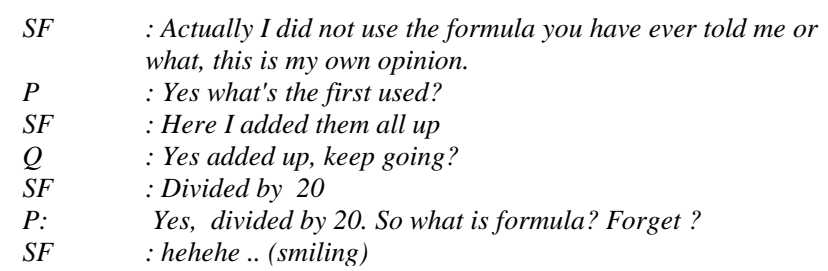

Based on a questionnaire of metacognitive activity, $\mathrm{F}$ students unsure the steps and strategies used are appropriate, although in interviews and work shows realize there is a mistake. Student F actually has difficulty in implementing the planned strategy (redflag: lack of progress) but still doing so, so student $\mathrm{F}$ experienced metacognitive vandalism (SF.6. (8) .lp.V).

\section{DISCUSSION}

In accordance with the purpose of this study is to describe the process of identification of metacognitive failure in solving mathematical problems. The use of a metacognitive activity questionnaire can provide guidance on the metacognitive activities undertaken in the problem-solving process. Students acknowledge or unsure in relation to the indicators in the problem-solving process have a distinct tendency towards the potential for metacognitive failure. This is in contrast to that of previous researchers, where redflag and mathematical failure were extracted from discussions of the work process [6],[9]).

Students filled "yes" in the questionnaire Metacognitive activity indicates having metacognitive activity appropriate to the indicator, but it did not guarantee whether the metacognitive activity performed successfully or failed [7].

The potential for redflag and metacognitive failure if the student did not write or write down but incorrectly related to the indicators of the problem-solving stage of his work, this condition allows for metacognitive blindness. Conversely, students fill out "no/unsure in the questionnaire metacognitive activity did not guarantee to have failed in performing metacognitive activities in accordance with the indicators of the problem-solving stage [7]

If the student writes correctly about the indicator on the answer sheet even if it does not acknowledge it as if there is a redflag that did not exist then the metacognitive mirage occurs. While metacognitive vandalism occurs when students were wrong in following up redflag that occurred.

Table 3 Symbols and Meanings

\begin{tabular}{|c|c|}
\hline Symbol & Meanings \\
\hline $\mathrm{A}$ & Understand \\
\hline B & Analyze \\
\hline $\mathrm{C}$ & Explore \\
\hline $\mathrm{D}$ & Plan \\
\hline $\mathrm{E}$ & Implement \\
\hline $\mathrm{F}$ & Verify \\
\hline $\mathrm{a}, \mathrm{b}, \mathrm{c}, \mathrm{d}, \mathrm{e}, \mathrm{f}$ & Problem solving phase indicator \\
\hline $\mathrm{AK}$ & Assess Knowledge \\
\hline $\mathrm{AU}$ & Assess Understanding \\
\hline AAS & Assess Appropriate strategy \\
\hline AES & Assess Execution \\
\hline AP & Assess Progress \\
\hline $\mathrm{AR}$ & Assess Result \\
\hline & Proces ... _. \\
\hline & Metacognitive activity \\
\hline & Redflag: lack of progress, Error detection \\
\hline & $\begin{array}{l}\text { Redflag: anomalous result solving problem } \\
\text { episode }\end{array}$ \\
\hline
\end{tabular}

Student $\mathrm{W}$ acknowledges metacognitive activity in ensuring the understanding of what is being asked in the problem, ie assessing the understanding understanding of the problem [7] but unaware of the redflag (anomalous result).

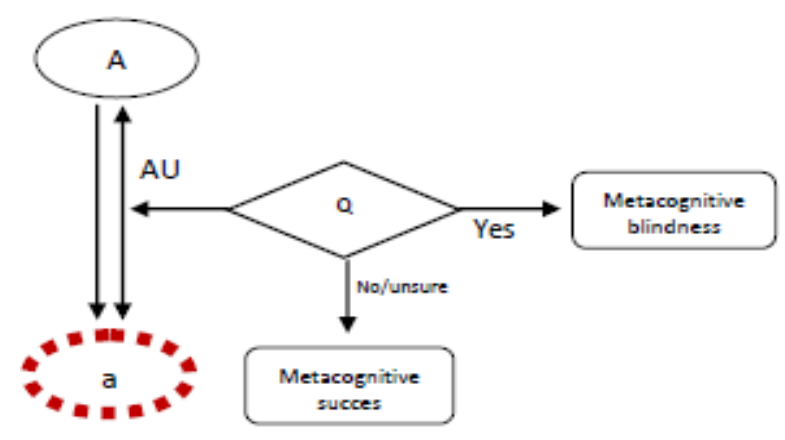

Fig. 10. Metacognitive Blindness of student W 
Student $\mathrm{V}$ in analyzing the problem by underlining the problem sheet to get the information. The move is appropriate, but student $\mathrm{V}$ does not admit it, either in the questionnaire of metacognitive activity or in the interview.

Student V fails the asess strategy appropriateness process in choosing a strategy to get information from the problem, where the steps and information obtained are appropriate but do not acknowledge them, thus student $\mathrm{V}$ experience metacognitive mirage.

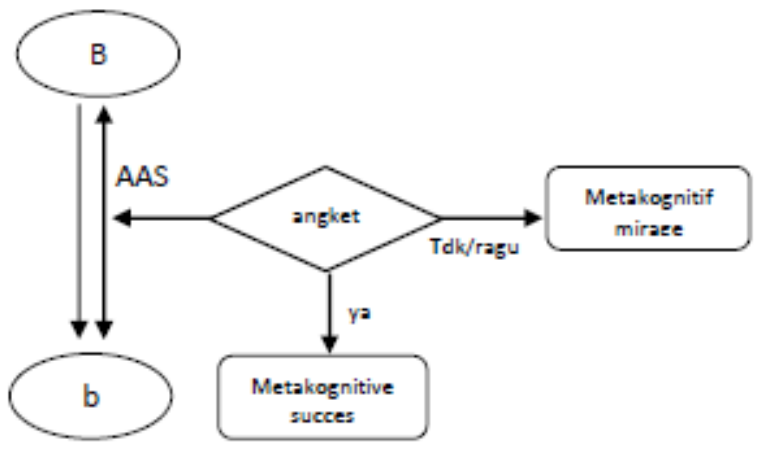

Fig. 11. Metacognitif Mirage Schem of Student V

While student A recognized to do metacognitive activity in the form of assess strategy approproateness [7] by considering various approaches that could be tried to solve the problem. The process of appointment strategy appropriateness by student A failed where initially student $A$ recognized that one of the approaches chosen were wrong because it was not based on the theory that supports. But in the next process the student uses again as the basis for decision making, thus student A experiences metacognitive vandalism.

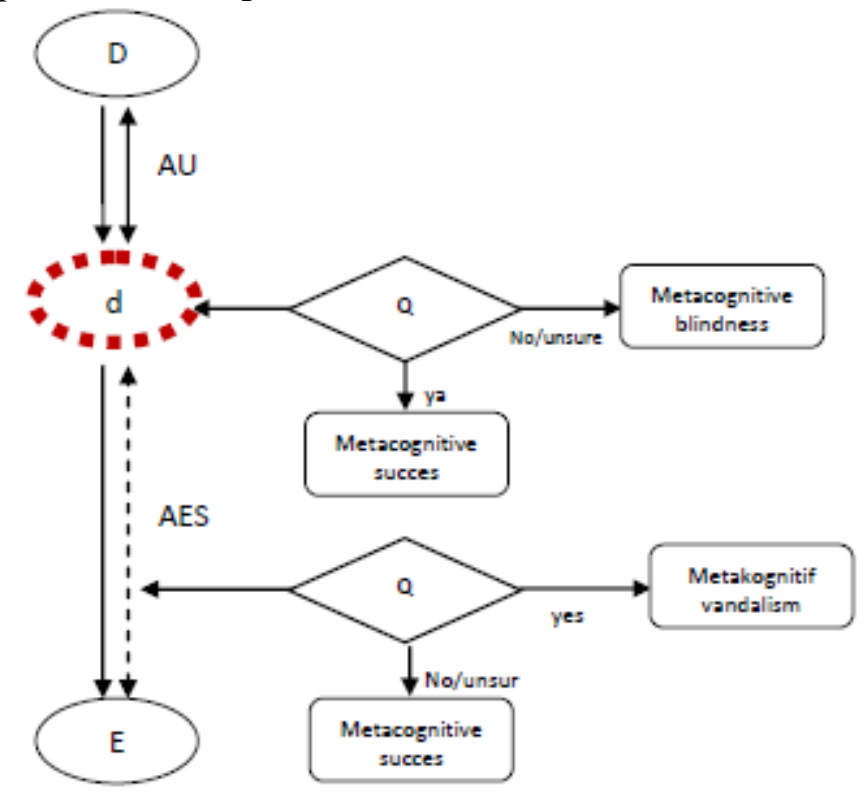

Fig. 12. Metacognitif Vandalism Schem of Student A

Other metacognitive vandalism also occurs student $F$, where F student doubt the rules or formulas used in the calculations, but continue the process, failing in the asess strategy execution process.
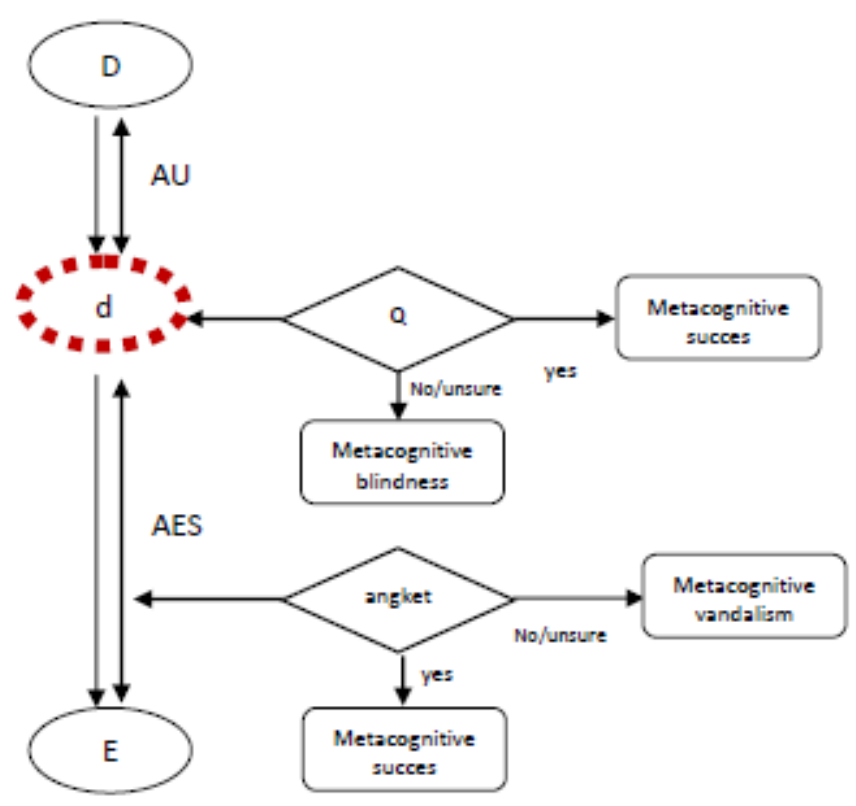

Fig. 13 Metacognitif Vandalism Schem of Student F

\section{CONCLUSSION}

The use of metacognitive questionnaires and interviews is expected to excite metacognitive failures well, this is important because if confirmation of a metacognitive failure is not done, it can make unilateral unilateral claims. The next research development can use other methods, such as think aloud so that the data obtained more valid.

The results of this study indicated that metacognitive blindness occurs when students recognized to having metacognitive activity by answering "yes" in a questionnaire of metacognitive activity in accordance with an indicator of problem-solving stage but failing to detect the redflag occurring in that stage.

Metacognitive mirage occurs when the student does not acknowledge having done the actual metacognitive activity already done, feeling a redflag actually does not occur.

Metacognitive vandalism occurs when the student admitted or did not admit to having metacognitive activities and successfully detected redflag, but follows up with inappropriate activities.

\section{REFERENCES}

[1] J. Livingstone, Metacognition: An Overview, 1997, (Online), www.gse.buffalo.edu/fas, December 2, 2014.

[2] E. R. Lai, Metacognition: A Literature Overview, Research Report, Pearson, 2011. (Online), http://www.pearsonassessments.com/

[3] NCTM, Principles and Standards for School Mathematics.The National Council of Teachers of Mathematics, Inc.1906 Association Drive, Reston, 2000, VA 20191-9988.

[4] J. Garofalo, F. K.. Lester, Metacognition, cognitive monitoring, and mathematical performance. Journal for Research in Mathematics Education, 1985, 16, 163-176. 
[5] A. F. Artzt, E. Armour-Thomas, Development of a cognitivemetacognitive framework for protocol analysis of mathematical problem solving in small groups. Cognition and Instruction, 1992, 9(2), 137-175. (Online), http://www.jstor.org/stable/3233531, diakses tanggal 11 April 2016.

[6] M. Goos, Understanding metacognitive failure. Journal of Mathematical Behavior, (Online), 2002, 21(3), 283-302,

[7] M. Goos, P. Galbraith, P. Renshaw, A money problem: a source of insight into problem solving action. International Journal for Mathematics $\begin{array}{lll}\text { Teaching and } 2000 . & \end{array}$ http://www.cimt.plymouth.ac.uk/journal/pgmoney.pdf

[8] K. Ee Dawn Ng, Partial Metacognitive Blindness in Collaborative Problem Solving, in L. Sparrow, B. Kissane, \& C. Hurst (Eds.), Shaping the future of mathematics education: Proceedings of the 33rd annual conference of the Mathematics Education Research Group of Australasia. Fremantle: MERGA. 2010. https://eric.ed.gov/?id=ED520954

[9] G. Stillman, Applications and Modelling Research in Secondary Classrooms: What Have We Learnt?, 12th International Congress on Mathematical Education, 8 July - 15 July, 2012, COEX, Seoul, Korea, (Online), https://www.acu.edu.au/_data/assets/pdf_file/0006/462948/Gloria_Still man - ICME - Regular Lecture.pdf,.

[10] N. Huda, Subanji, T. Nusantara, Susiswo, A. Sutawidjaja, S. Rahardjo, University students' metacognitive failures in mathematical proving investigated based on the framework of assimilation and accommodation, Educational Research and Reviews. 2016. Vol. 11(12), pp. 1119-1128, 23 June, 2016.DOI: 10.5897/ERR2016.2721. https://eric.ed.gov/?id=EJ1104561

[11] N. Prakitipong, S. Nakamura, Analysis of Mathematics Performance of Grade Five Students in Thailand Using Newman Procedure. Journal of International Cooperation in Education, 2006, vol 9(1):111-122.

[12]M.T. Siniguian, Students Difficulty In Solving Mathematical Problems, International Journal of Advanced Research in Engineering and Applied $\begin{array}{lllll}\text { Sciences: } & \text { Vol. } & 6, & \text { No. } & \text { 2, }\end{array}$ http://www.garph.co.uk/IJAREAS/Feb2017/1.pdf

[13] J.W. Creswell, Educational Research Design: Planning, Conducting, and Evaluating Quantitative and Qualitatve Research, Boston: Pearson. 2012.

[14] J.W. Creswell, Research Design, Yogyakarta: Pustaka Pelajar, 2014. 